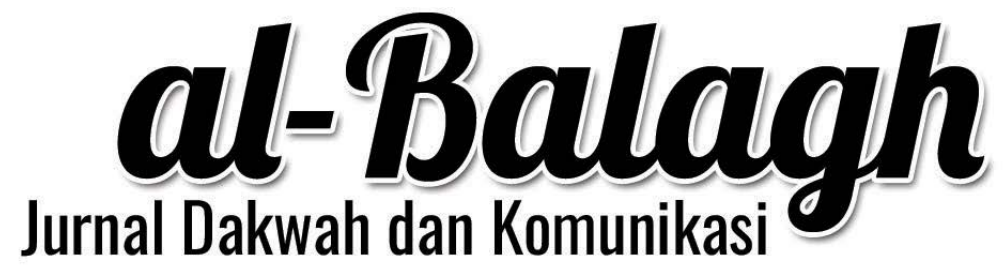




\title{
al-Balagh
}

ISSN: 2527-5704 (P) ISSN: 2527-5682 (E)

Vol. 2, No. 1, Januari - Juni 2017

\section{Editorial Team}

\section{Editor-In-Chief}

Imam Mujahid, IAIN Surakarta

\section{Editorial Board}

Kamaruzzaman bin Yusof, Universiti Teknologi Malaysia Waryono Abdul Ghafur, UIN Sunan Kalijaga, Yogyakarta

Moch. Choirul Arif, UIN Sunan Ampel, Surabaya

Imas Maesaroh, UIN Sunan Ampel, Surabaya

Syakirin Al-Ghazali, IAIN Surakarta

Ahmad Hudaya, IAIN Surakarta

M. Endy Saputro, IAIN Surakarta

Managing Editor

Akhmad Anwar Dani, IAIN Surakarta

Ahmad Saifuddin, IAIN Surakarta

Rhesa Zuhriya Briyan Pratiwi, IAIN Surakarta

\author{
Alamat Redaksi : \\ Fakultas Ushuluddin dan Dakwah, IAIN Surakarta \\ Jl. Pandawa No. 1, Pucangan, Kartasura, \\ Sukoharjo, Jawa Tengah 57168 \\ Phone : +62 $271-781516$ \\ Fax : $+62271-782774$
}

Surel : journal.albalagh@gmail.com, journal.albalagh@iain-surakarta.ac.id

Laman : http://ejournal.iainsurakarta.ac.id/al-balagh 


\section{al-Balagh}

ISSN: 2527-5704 (P) ISSN: 2527-5682 (E)

Vol. 2, No. 1, Januari - Juni 2017

\section{Daftar Isi}

Negosiasi Dakwah dan Politik Praktis: Membaca Orientasi Organisasi Sayap Keagamaan Islam pada Partai Nasionalis Bayu Mitra A. Kusuma dan Theresia Octastefani

Dialektika Komunikasi Intrapersonal: Mengkaji Pesona Komunikasi dengan Diri Sendiri

Ferry Adbi Dharma

Islam Agama Teror? (Analisis Pembingkaian Berita Media Online Kompas.com dalam Kasus Charlie Hebdo)

Ismail Fahmi Arrauf Nasution dan Miswari

Realitas Sosial Anak Yatim Di Kota Padang dalam Perspektif Pemberdayaan Masyarakat

Mardan Mahmuda

Pengembangan Kompetensi Profesi Program Studi Komunikasi dan Penyiaran Islam

Zainul Abbas

Bimbingan dan Konseling dengan Pendekatan Rational Emotive Behavior Therapy untuk Penerima Manfaat Mubamad Abdul Kohar dan Imam Mujabid 


\section{al-Balagh \\ Jurnal Dakwah dan Komunikasi}

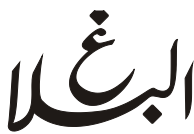

http://ejournal.iainsurakarta.ac.id/al-balagh

\section{DIALEKTIKA KOMUNIKASI INTRAPERSONAL: MENGKAJI PESONA KOMUNIKASI DENGAN DIRI SENDIRI}

Ferry Adhi Dharma

dialectic

intrapersonal

communication
Keywords:

\begin{abstract}
The dialectic of intrapersonal communication help us to understand several sides of metaphysics in the science of communication. At this level of communication, communication activities can be analyzed from the dialectic and the dialogue which is in monologue concept. Objectivity of communicative action will be traced from intersubjectivity of each individual. In this article, the communicative action will be reviewed by a phenomenal figure of Dimas Kanjeng Taat Pribadi. By reviewing and studying at this level of communication, we will try to understand the construction of knowledge, attitudes, and the subjective actions of individuals that necessitate a distinctive or enchanting communication style when they communicate with others.
\end{abstract}

\begin{abstract}
Abstrak
Dialektika komunikasi intrapribadi membantu kita untuk memahami sebagian sisi metafisika dalam ilmu komunikasi. Pada komunikasi tingkat ini, aktivitas komunikasi dapat dilihat melalui dialektika dan dialog yang ada dalam konsep monolog. Objektifitas dari tindakan komunikatif mampu ditelusuri dari adanya intersubjektifitas pada setiap individu. Dalam artikel ini tindakan komunikatif dikaji secara khusus melalui tokoh fenomenal Dimas Kanjeng Taat Pribadi. Dengan mengkaji dan mendalami level komunikasi intrapersonal yang terjadi, kita akan berusaha memahami konstruksi pengetahuan, sikap, dan tindakan subjektif dari individu yang meniscayakan gaya komunikasi yang khas atau mempesona saat berkomunikasi dengan orang lain.
\end{abstract}

DOI Number

10.22515/

balagh.v2il.483

Alamat korespondensi:

(C) 2017 IAIN Surakarta

e-mail: ferryadhidharma@gmail.com

ISSN: 2527-5704 (P) ISSN: 2527-5682 (E) 


\section{PENDAHULUAN}

Manusia, dalam posisinya sebagai makhluk sosial tentu terlibat dengan sejumlah aktivitas komunikasi yang bersifat dinamis. Baik di lingkungan keluarga, sekolah, maupun masyarakat, manusia mau tidak mau harus menjadi bagian dari kehidupan sosial budaya yang melingkupinya. Manusia dalam menjalankan aktivitasnya sehari-hari, memiliki keunikan masing-masing terkait dengan cara mereka dalam berkomunikasi. Salah satunya dalam kajian komunikasi intrapersonal atau komunikasi dengan diri sendiri, dimana kajian masih dipandang terlalu subjektif dan tidak dapat diketahui kebenarannya oleh orang lain atau dinilai secara umum.

Subjektivitas dalam komunikasi intrapersonal memang tidak sepenuhnya selaras dengan definisi ilmu komunikasi yang diyakini kebenarannya oleh kebanyakan ahli komunikasi di dunia. Secara terminologi, istilah atau kata komunikasi berasal dari kata Latin communis yang berarti "sama", communico, communicatio atau communicare yang berarti "membuat sama" (to make common). Istilah pertama (communis) paling sering disebut sebagai asal mula kata komunikasi, yang merupakan akar dari kata-kata Latin lainnya yang serupa. Komunikasi menyarankan bahwa suatu pikiran, suatu makna, atau suatu pesan dapat dianut secara sama (Mulyana 2010, 46).

Untuk mendalami eksistensi kajian komunikasi intrapersonal, tulisan ini akan membahas poin penting dari teori tindakan komunikatif yang dicetuskan oleh Habermas. Sebagai pemikir dan pencetus teori tindakan komunikatif, Habermas telah membagi rasionalitas dalam dua arah (tindakan nonkomunikatif dan tindakan komunikatif). Tindakan non-komunikatif dikenal dengan rasionalitas instrumental, yaitu dorongan tindakan yang membawa konotasi kesuksesan diri atau mengambil keuntungan secara pribadi melalui disposisi informasi yang berlebihan dan adaptasi cerdas dengan kondisi lingkungan (dinsensus). Sedangkan tindakan komunikatif lebih ditekankan pada tercapainya konsensus di antara peserta komunikasi. Semua berusaha mengatasi perbedaan subjektif dan menjamin adanya kesatuan pandangan objektif dan intersubjektivitas pada pemikiran dan 
tindakan mereka (Habermas 1984, 10).

Secara umum Habermas membatasi tindakan komunikatif seseorang dari tujuan tindakannya. Dalam hal ini ada pengakuan bahwa subjektivitas individu merupakan hal yang rasional dan menentukan dorongan tindakan non-komunikatif maupun komunikatif. Pembagian dua tindakan yang dilakukan oleh Habermas memunculkan pertanyaan bagi penulis, yaitu: apakah tindakan komunikatif memang diperuntukkan untuk komunikasi antar manusia saja (dua orang atau lebih) atau dengan kata lain apakah komunikasi intrapersonal bukan termasuk di dalam teori tindakan komunikatif? Untuk menjawab pertanyaan tersebut, penting bagi tulisan ini untuk memperjelas letak subjektivitas manusia dalam konsep komunikasi itu sendiri.

Untuk memperjelas letak subjektivitas dari tindakan komunikatif, tulisan ini berupaya menganalisis teori tindakan komunikatif dengan fenomena Dimas Kanjeng yang terjadi di Indonesia. Dimas Kanjeng terbukti dapat mempengaruhi banyak komunikan atau pengikutnya melalui pesona komunikasi yang dimiliki. Asumsinya, tindakan yang dilakukan ini bukan hanya bersifat rasional instrumental, melainkan lebih jauh mengkomunikasikan sejumlah simbol guna mendukung objektivitas dari tindakan komunikatif yang dimaksudkan oleh Habermas. Dengan demikian, tulisan ini selanjutnya bermaksud untuk mengkaji literaturliteratur yang relevan dengan teori tindakan komunikatif guna menjelaskan peristiwa-peristiwa komunikasi yang dilandasi oleh disensus.

\section{METODE PENELITIAN}

Artikel ilmiah ini disusun dengan menggunakan metode studi literatur. Analisis dilakukan tidak berdasarkan studi lapangan secara langsung, melainkan berdasarkan analisis kajian melalui sejumlah literatur, baik melalui sumber pustaka buku, jurnal, maupun sumber lain yang relevan dan mendukung. Lebih lanjut, analisis dalam tulisan ini akan difokuskan pada kajian komunikasi intrapersonal; terkait konsep dialog, dialektika, 
dan monolog yang meniscayakan konstruksi sosial dan mengarah pada pesona komunikasi seorang individu. Secara khusus, kasus yang diambil adalah fenomena Dimas Kanjeng Taat Pribadi yang populer dalam waktu singkat dengan memanfaatkan konstruksi sosial melalui simbol-simbol komunikasi yang menjadi atribut sosial pada dirinya.

\section{TAAT PRIBADI, PESONA KOMUNIKASI DALAM ATRIBUT SOSIAL}

Kita tak dapat memungkiri bahwa terdapat sejumlah orang yang mampu berkomunikasi dengan baik, dengan "bukan sekedar bicara", tanpa mempelajari ilmu komunikasi. Misalnya saja, fenomena Dimas Kanjeng yang baru-baru ini populer di media massa karena diketahui berhasil menipu banyak orang selama bertahun-tahun sebelum terbongkarnya kasus pembunuhan berencana yang dilakukan terhadap pengikutnya sendiri.

Ini tentu dapat dijadikan pelajaran bagi kita semua agar tidak mudah tertipu dengan simbol komunikasi yang digunakan oleh seseorang. Perlu adanya penalaran dan dialektika intrapribadi bagi seseorang untuk memahami setiap simbol yang disampaikan oleh seseorang agar tidak mengandalkan penilaian umum sebagai referensi utama dalam memahami makna pesan yang simbolis.

Melalui uraian di atas, adanya pandangan umum tidak dapat dipisahkan dari budaya setempat. Pada dasarnya ekspresi manusia yang rasional hendaknya memang memiliki sifat tindakan yang dimengerti oleh komunitas mereka, dimana aktor berhubungan dengan suatu pandangan objektif. Kondisi validitas ekspresi simbolik tersebut mengacu pada latar belakang pengetahuan intersubjektif sebuah komunitas komunikasi. (Habermas 1984, 13).

Khususnya dalam konteks budaya, ekspresi simbolis sebuah komunitas merupakan internalisasi secara turun-temurun. Ketika ada anggota baru dalam sebuah lingkungan sosial, maka bukan hanya anggota 
tersebut yang diminta untuk mengikuti ekspresi komunitas barunya, melainkan anggota komunitas yang lain hendaknya menghargai nilainilai yang dibawa oleh anggota baru dari pengalaman hidup di komunitas lamanya.

Hal ini dapat dijadikan sebagai penjelasan bahwa terdapat penghargaan terhadap nilai-nilai subjektif dalam tatanan sosial-budaya. Jika sikap empati dan simpati ditiadakan, maka akan muncul kemungkinan terjadinya konflik sosial di antara mereka. Sebab, pengalaman hidup seseorang berhubungan secara kontingen dengan keyakinan orang itu sendiri. Asumsinya, semakin jelas tindakan seseorang yang sesuai dengan objektivitas terencana-rasional, maka semakin sedikit pula kita butuh pertimbangan psikologis untuk menjelaskannya. Di sisi lain, ketika tindakan itu dilakukan secara subjektif, maka akan kurang optimal jika dinilai secara objektif (Habermas 1984, 103).

Artikel ini lebih lanjut menelaah adanya subjektivitas komunikasi yang dilakukan oleh Taat Pribadi guna menganalisis bagaimana konstruksi dan presentasi diri yang dilakukan oleh Taat Pribadi. Perhatian publik berhasil direbut setelah Dimas Kanjeng muncul sebagai aktor penggandaan uang dan dugaan pembunuhan berencana terhadap mantan pengikutnya. Selain itu, Dimas Kanjeng juga dilaporkan beberapa mantan pengikutnya atas tuduhan penipuan yang bernilai ratusan juta hingga milyaran rupiah.

Nama Dimas Kanjeng baru ditambahkan oleh Taat Pribadi ketika sudah dikenal oleh masyarakat luas sebagai "orang sakti" dalam mendatangkan dan menggandakan uang secara misterius. Gelar itu diberikan oleh Ketua Asosiasi Kerajaan dan Kraton Indonesia (AKKI) (Kompas.com 2016,1). Hal tersebut tentu saja dapat menguatkan keyakinan pengikut Taat terhadap kisah raja-raja Jawa terdahulu yang penuh dengan unsur mistis, baik secara tersurat maupun tersirat dalam dongeng, mitos, dan drama kolosal, seperti Misteri Gunung Merapi serta Angling Dharma.

Pada dasarnya, muncul sebuah distorsi dari makna yang dilekatkan pada nama atau sebutan Dimas Kanjeng, di mana Dimas Kanjeng Taat 
Pribadi justru lebih dikenal dengan uang gaibnya, dan bukan melalui garis keturunannya. Sebuah realitas yang dengan sengaja diciptakan oleh Taat Pribadi melalui berbagai cara, salah satunya adalah aksi mengeluarkan uang dari balik jubah besar. Selain itu, Taat Pribadi juga meyakinkan pengikutnya melalui ritual mistis seperti penarikan barang-barang gaib berupa emas, benda pusaka, perhiasan, dan lain sebagainya.

Sampai tulisan ini dibuat, masih banyak pengikut Taat Pribadi yang rela bertahan di tenda-tenda di sekitar padepokannya dan percaya bahwa Taat tidak bersalah dan benar memiliki ilmu yang tidak dimiliki oleh orang pada umumnya-kanujela. Mereka meyakini adanya ilmu ajaib Taat berdasarkan pada apa yang telah dilihat, yaitu memindahkan ataupun mendatangkan benda secara gaib, meskipun telah diketahui oleh masyarakat luas bahwa barang-barang tersebut palsu dan didatangkan melalui trik yang menipu.

Segala atribut dan simbol yang digunakan oleh Taat pun begitu meyakinkan, mulai dari penambahan gelar Kanjeng, jubah, hingga singgasana yang dibuat menyerupai tempat duduk para sultan. Sikap dan perilaku Taat pun dikonstruksi layaknya seorang sultan yang sesungguhnya. Selain dapat menunjukkan foto dirinya bersama pejabat-pejabat negara, Taat juga beristri lebih dari satu seperti kebiasaan para raja. Hal tersebut tentu dapat berpotensi menambah keyakinan pengikut Taat yang sebelumnya sudah takjub dengan kemampuan Taat mendatangkan uang.

Makna yang dibangun tersebut sangat kuat hingga memunculkan realitas dan kesadaran palsu bagi pengikutnya. Taat Pribadi terbukti mampu menyelaraskan keduanya sesuai dengan apa yang diekspektasikan, hingga semua pengikutnya — tidak terkecuali bagi mereka yang berpendidikansempat percaya pada satu kesimpulan bahwa Taat Pribadi wajib diagungkan.

Sejatinya ilmu komunikasi adalah ilmu yang dapat dipelajari oleh semua orang melalui interaksi sosial. Pada hakikatnya, bayi tidak lahir dengan pemahaman yang jelas tentang siapa diri mereka. Sebaliknya, seseorang akan mengembangkan diri pada proses komunikasi dengan orang lain. Seperti saat mengimpor atau menginternalisasi perspektif 
mereka sehingga mereka menjadi saling mengenali perspektif masingmasing dan siapa diri mereka (Smith 1977, 42).

Tidak jarang misalnya, seseorang yang memiliki pengetahuan dan keahlian yang baik akan dijadikan sebagai pemimpin opini dalam sebuah struktur sosial. Kendati demikian, tidak semua pemimpin opini menggunakan pengetahuan dan keahlian komunikasinya untuk mencapai konsensus. Ini relevan dengan pendapat Gramsci mengenai "The notion of 'the intellectuals' as a distinct social category independent of class is a myth. All men are potentially intellectuals in the sense of having an intellect and using it, but not all are intellectuals by social function" (Gramsci 1999, 131).

Penjelasan di atas dapat dimaknai bahwa manusia memiliki naluri untuk selalu belajar berkomunikasi dan mengenal satu sama lain. Terkait hal ini, semua orang berpotensi memiliki keahlian dan menggunakannya, tetapi tidak semua orang menggunakan keahlian tersebut untuk kepentingan sosial. Bahkan, tidak jarang ilmu pengetahuan digunakan untuk menghegemoni orang lain demi keuntungan pribadi seperti fenomena Dimas Kanjeng.

Merujuk pernyataan di atas, muncul adanya pesona komunikasi yang dimaksudkan sebagai konstruksi simbol-simbol komunikasi agar dapat berkomunikasi dengan "indah". Hal ini dapat dinilai sebagai keahlian atau kemampuan seseorang dalam berkomunikasi satu sama lain, yang mana membutuhkan waktu untuk mempelajarinya dengan selalu menggali potensi komunikatif yang ada di dalam diri. Asumsinya, ketika saat ini perkembangan teknologi komunikasi telah berkembang sangat pesat dan banyak merubah sifat-sifat komunikasi itu sendiri, tetapi proses dialogis antar manusia akan tetap ada dan selalu ada dalam kehidupan seharihari. Hal ini terjadi secara alami karena manusia tidak dapat lepas dari kontak dan konteks sosial, meskipun banyak aspek yang mungkin dapat berpengaruh terhadapnya.

Fokus pada kajian komunikasi, muncul istilah dramaturgi sebagai bentuk penyesuaian diri pada diri individu terhadap setiap lapisan 
lingkungan yang ada di sekitarnya. Dalam hal ini, terdapat sejumlah subjektivitas yang secara sengaja dikelola oleh aktor komunikasi agar tindakan yang diambil sesuai dengan apa yang diharapkan oleh audiens. Sebelum aktor mengungkapkan sesuatu pada publik, aktor terlebih dahulu mengungkapkan sesuatu pada dirinya sendiri, yang mana merujuk pada pandangan subjektifnya.

Konsep dramaturgi ini berkenaan dengan pandangan Erving Goffman dalam teorinya mengenai presentational self. Teori ini merupakan suatu metafora yang menjelaskan tentang bagaimana seorang komunikator mempresentasikan dirinya (Littlejohn 2011, 101). Lebih lanjut, teori ini menjelaskan tentang asumsi dasar bahwa setiap orang akan selalu memahami tentang setiap kejadian yang ada kehidupan sehari-hari sehingga adanya interpretasi dari situasi yang diciptakan merupakan pengertian dari situasi itu sendiri (Littlejohn 2011, 101). Dengan demikian, dapat dikatakan bahwa setiap individu akan selalu memaknai-konstruksi pemahaman — setiap peristiwa yang pernah dialaminya, untuk kemudian dipahami ke dalam perilaku-perilaku dalam situasi tertentu.

Sebut salah satu contohnya adalah terkait pandangan-konsep formal memberikan dasar penilaian yang dibagikan oleh seorang agen dan penerjemahnya. Penerjemah dapat menafsirkan tindakan rasional sedemikian rupa hingga mampu menangkap unsur penipuan atau penipuan diri. Seseorang dapat mengekspos strategi laten karakter presentasi diri mereka dengan membandingkan muatan isi dari ucapan, yaitu tentang apa yang dikatakan dan dengan cara apa itu dikatakan. Penafsir dapat lebih jauh lagi mengungkap secara sistematis terdistorsinya karakter pada proses pemahaman dengan menunjukkan bagaimana seseorang mengekspresikan diri secara subjektif, jujur, dan belum objektif dalam mengatakan sesuatu selain dari apa yang mereka ketahui (Habermas 1984, 105).

Analisis uraian di atas, apabila dikaitkan dengan teori tindakan komunikatif, maka konteks dramaturgi ini tergolong sebagai tindakan rasional instrumental, dan bukan tindakan komunikatif. Lebih jauh, tindakan ini juga dapat memungkinkan sebuah konsensus, meskipun 
Habermas sendiri telah setuju jika dramaturgi dimaksudkan sebagai model tindakan dialogis yang subjektif.

Merujuk pada pendapat Plato, bahwa dialog pada dasarnya berhubungan dengan estetika kuno yang bersifat ideal. Konteks estetika ini mengarah pada seni imitasi dari sebuah wujud. Terkait hal ini, Plato telah mengembangkan seni penalaran yang berusaha menjadi lebih dari sekedar seni, yaitu sebuah metode menangkap kebenaran dari subjek (Nikulin 2000, 3). Konkretnya, setiap orang pada dasarnya mampu terlihat mempesona ketika berdialog dengan orang lain sehingga perlu pemahaman tersendiri terkait bagaimana memahami gaya komunikasi setiap orang melalui proses penalaran dialog dengan tujuan untuk meminimalisir tindak persuasif negatif yang mungkin saja muncul.

Berkenaan dengan konsep di atas, Taat Pribadi merupakan sosok dengan pesona dan gaya komunikasi yang khas. Hal ini terkait atribut sosial yang kemudian tersemat pada dirinya, citra diri, sampai pada pemunculan reputasi baik atas nama seorang Taat Pribadi. Lebih lanjut, kekhasan dari komunikasi yang dilakukan juga dapat diberi muatan retorika politisyakni hegemoni-bagi sejumlah orang.

Meminjam definisi Heidegger, dunia adalah "that in terms of which buman reality makes known to itself what it is" (Sartre 1956, 104). Subjektivitas seseorang berperan dalam menentukan segala kemungkinan yang akan didapatkan sebelum melakukan sebuah tindakan. Selain itu, individu juga memegang kendali atas dirinya sendiri dalam membentuk sebuah kesadaran sosial. Dengan demikian, konstruksi diri pada akhirnya dapat berubah menjadi konstruksi realitas dalam waktu sekejap. Kendati demikian, realitas sendiri tidak serta merta diterima sebagai hal yang nyata terjadi dalam kehidupan bermasyarakat. Guna menganalisis hal ini, para filsuf dan pemikir kemudian mengidentifikasikan sejumlah pertanyaan mengenai "apa itu realitas dan pengetahuan?", "apa yang nyata?", dan "bagaimana hal tersebut diketahui?" (Berger dan Luckmann 1966, 13).

Muncul kebingungan dalam menyikapi mana yang benar dan 
mana yang salah. Sebagian dari alasan yang diungkapkan telah melalui penalaran, ada kemiripan dari mana yang benar dan mana yang salah. Hal inilah yang kemudian terjadi pada konteks argumen. Misalnya saja, ada sebagian orang memiliki fisik yang baik, sementara yang lain hanya memiliki kemiripan dengan itu, tetapi dengan memaksa diri mereka keluar dan berpenampilan seragam. Kemudian, ada beberapa orang lain yang cantik karena kecantikan mereka sendiri, sementara yang lain memiliki kecantikan atau keindahan karena tipu daya mereka. Begitu pula untuk benda mati. Beberapa merupakan emas dan perak yang asli, sedangkan sebagian lagi tidak, tergantung respon dari indera kita. Dengan cara yang sama penalaran dan sanggahan kadang-kadang nyata dan kadang-kadang tidak, tetapi terlihat nyata (Aristotle 1978, 11).

Terkait hal ini, ada dua bentuk penalaran pada konstruksi realitas yang diciptakan oleh individu saat berkomunikasi. Pertama, penalaran yang dilakukan oleh seorang ahli komunikasi, dan yang kedua adalah penalaran yang dilakukan oleh seorang yang bukan ahli komunikasi. Ketika prinsip teori tindakan komunikatif Habermas digunakan, maka konstruksi realitas yang ada hanya akan ditafsirkan sebagai tindakan rasional instrumental saja dan kurang mengindahkan aspek lain yang melingkupinya.

Pemaknaan simbolis dari tindakan ini bukan hanya lemah, tetapi juga meniadakan motif konstruksi seseorang dan sistematika konstruksi itu sendiri. Prinsipnya, sebuah tindakan komunikatif justru akan dimulai dari tindakan rasional instrumental, di mana seseorang akan mengolah subjektivitasnya untuk meniscayakan objektivitas dalam komunitasnya. Benar jika terdapat intersubjektivitas dalam tindak komunikatif yang dimaksudkan oleh Habermas. Kendati demikian, untuk mengetahui wujud kesepakatan tersebut, perlu analisis lebih jauh terdapat subjektivitas yang lebih dominan dari subjektivitas lainnya, terutama dalam produksi dan sosialisasi makna normatif pada proses serta tindakan komunikasi yang dilakukan.

Peran individu dalam interaksi sosial sendiri bersifat mutlak. 
Perwujudan konsensus dengan diri sendiri juga diperlukan untuk mencapai konsensus dengan orang lain atau masyarakat umum. Prinsipnya, sebuah konflik tidak akan mungkin statis atau selesai jika persatuan tidak bangkit melawan dirinya sendiri. Jauh dari perjuangan, ketika ini muncul, ada di dalamnya, ini adalah kesatuan yang memungkinkan. Tidak hanya kesatuan ini mewakili ikatan intim antara masing-masing pihak dan kelompok, juga merupakan makna dari relasi antagonis itu sendiri (Sartre 1991, 67).

Berdasarkan pemahaman di atas, dapat dikatakan bahwa ketika individu memainkan peran yang berbeda dengan konsep kebenaran yang dimiliki, maka individu tersebut telah berkomunikasi dengan diri sendiri untuk menentukan tindakannya. Bukan hanya untuk mencapai konsensus, melainkan juga disensus agar dirinya aman dan tidak dikucilkan selama semua subjek sepakat untuk mengakhiri konflik secara objektif.

Adapun konteks pesona dan kedewasaan komunikasi seseorang tidak serta merta hadir karena pengaruh komunitas tutur. Dalam hal ini, seseorang memiliki kemampuan untuk berdialog dan berdialektika dengan dirinya sendiri sehingga melalui kemampuan tersebut, seseorang memungkinkan dirinya sendiri untuk mencapai sebuah disensus dan konsensus dalam satu rangkaian tindakan rasional. Lebih khusus, terkait dialektika yang digunakan, ini dapat dijadikan sebagai salah satu metode untuk mencari kebenaran melalui pemikiran pribadi, di mana seseorang dapat melatih pemikirannya agar tidak melakukan tindakan yang salah. Lebih jauh lagi, dialektika ini akan berguna dalam menentukan sikap dan tindakan seseorang di dalam pergaulan sosial, yang sangat dialogis dan dinamis.

\section{MONOLOG: DIALEKTIKA DAN DIALOG}

Sejauh ini, kajian monolog lebih kerap dikaitkan dengan pertunjukan seni-budaya, yang mana mengarah pada proses verbal atas peran seorang aktor tanpa lawan main. Berbicara sendiri, mbatin, maupun bergumam, bisa jadi merupakan beberapa contoh dari konteks monolog yang dimaksud. 
Meski konteks monolog dapat dikatakan kurang mendapat perhatiandibandingkan dengan dialog-dalam kajian ilmu komunikasi, tetapi di satu sisi, monolog sendiri sebenarnya merupakan bentuk komunikasi intrapersonal yang dilakukan setiap individu dan dapat diwujudkan dalam tindakan yang bersifat objektif.

Beralih pada tindakan komunikatif, tindakan ini mengarah kepada hubungan komunikasi dan tindakan di antara paling sedikit dua orang atau lebih yang membentuk hubungan interpersonal (baik dalam arti verbal maupun ekstra verbal). Dalam hal ini ada usaha dari aktor untuk mencapai sebuah pemahaman tentang situasi tindakan dan rencana tindakan yang akan dilakukan agar tindakan tersebut selaras dengan cara yang telah disetujui (Nuris 2016, 54-55).

Terkait pemahaman di atas, apabila komunikasi intrapribadi atau monolog dianggap sebagai tindakan non-komunikatif, maka anggapan tersebut secara otomatis meragukan validitas dari objek yang dihasilkan dengan adanya intersubjektivitas dalam komunitas tutur. Guna menelusuri validitas dari monolog, ilmu komunikasi dapat melibatkan disiplin psikologi sebagai disiplin ilmu yang mengkaji sifat-sifat manusia serta aspek psikis manusia dalam pengaruhnya terhadap tindakan komunikasi yang dilakukan.

Ada kemungkinan untuk memahami bahwa monolog bisa membangun ikatan yang dekat dengan seseorang. Kendati demikian, hal tersebut merupakan hasil yang tidak terduga bahwa monolog, untuk tingkat yang sama seperti dialog, juga dapat menjadi sumber dukungan, harapan, makna hidup, dan perasaan aman, meskipun ditujukan pada pendengar yang diam. Untuk mencoba menjelaskan fakta ini, seseorang dapat mengajukan hipotesis interpretatif bahwa monolog memenuhi metafungsi dalam situasi di mana itu adalah satu-satunya, atau jelas berlaku, maupun bentuk kegiatan dialogis intern yang diambil (Puchalska-Wasyl 2010, 76). Dengan kata lain, jika seseorang mengalami kesulitan untuk masuk ke dalam sebuah dialog batin yang mengandung sumber dukungan yang lebih khas, maka ia akan mencoba untuk memenuhi kebutuhan ini 
dengan berbicara pada pikirannya, seakan-akan orang lain mendengarkan dan memahami apa yang sedang dibicarakan dengan dirinya.

Pendapat di atas menunjukkan pada kita bahwa terdapat dialog di dalam monolog itu sendiri. Dialog yang terjadi akan mencapai derajat yang sama ketika seseorang mampu membayangkan dirinya sendiri sebagai komunikator dan komunikan pada saat yang sama ketika melakukan komunikasi intrapribadi.

Masih terkait monolog, berkomunikasi dengan diri sendiri nyatanya juga berguna untuk meyakinkan diri sendiri terhadap simbol maupun argumen yang disampaikan oleh orang lain kepada kita. Kita mungkin memiliki eksistensi dalam berdialog sebagai makhluk yang berkomunikasi satu sama lain, di saat kita berbicara dengan orang lain. Kendati demikian, ketika kita sampai pada satu kesimpulan dengan menerima dan menolak beberapa argumen orang lain, maka kita telah menggunakan metode yang lengkap, yakni rangkaian metode penalaran tradisional yang disebut dengan dialektika. Dalam konteks ini, seseorang dapat menggunakan dialektika di dalam dialog yang dilakukan, ataupun tidak menggunakannya, dan dapat juga menggunakannya di luar dialog (Nikulin 2000, ix).

Mempelajari perilaku komunikasi, baik yang berkenaan dengan dialog, monolog, maupun dialektika, pada dasarnya memang diperlukan untuk memahami mekanisme perilaku sosial. Apakah kemudian mekanisme-mekanisme yang terlibat dalam transaksi interkasi atau mereka memungkinkan pola yang lebih gigih pada organisasi sosial. Hal ini terjadi karena individu-individu yang berpartisipasi dalam interaksi sosial dan memiliki hubungan abadi satu sama lain, tidak dapat melakukannya tanpa sejumlah informasi yang memadai. Banyak dari informasi ini dibagikan melalui perilaku yang khusus agar menjadi informatif (Smith 1977, 458).

Pada hakikatnya, manusia memiliki perasaan dan pikiran, yang mana setiap hari akan berdialog secara kontingen untuk menentukan sikap dan tindakannya. Harmonisasi dari keduanya menjadi penting agar dapat menghasilkan sikap yang sesuai dengan norma-norma yang ada 
di masyarakat. Konsep inilah yang secara tidak langsung merujuk pada bentuk sistem kebaikan manusia yang ada dalam pikiran, sikap, dan tindakannya. Manusia dapat menentukan apa yang ingin dilakukan setelah berkomunikasi dengan dirinya sendiri. Konteks ini merupakan bentuk komunikasi yang khas, dan meniscayakan sistem kebaikan yang berbeda pada tiap individu.

Terkait pemahaman di atas, aspek budaya di sisi lain juga memiliki peran yang kuat dalam menentukan tindakan individu. Hal ini dapat dilihat dari penjelasan Pierre Bourdieu $(1977,163)$ berikut:

One of the effects of the ritualization of practices is precisely that of assigning them a time -i.e. a moment, a tempo, and a duration -which is relatively independent of external necessities, those of climate, technique, or economy, thereby conferring on them the sort of arbitrary necessity which specifically defines cultural arbitrariness

Pierre Bourdieu menambahkan bahwa setiap peraturan yang dibuat dalam sebuah komunitas cenderung menghasilkan (derajat yang sangat berbeda dan dengan cara yang sangat berbeda) naturalisasi yang berdasar pada kesewenang-wenangan pribadi. Semua mekanisme yang dibuat cenderung menghasilkan efek ini; yang paling penting dan yang terselubung dengan baik adalah kepastian dialektika pada tujuan yang objektif dan aspirasi agen, dari mana muncul pembatasan makna, yang biasa disebut dengan makna realitas atau korespondensi antara kelas objektif dan kelas yang diinternalisasi, struktur sosial dan struktur mental, sebagai dasar bentuk kepatuhan yang paling bisa dihilangkan dengan tatanan yang dibuat (Bourdieu 1977, 164). Pengalaman yang muncul akibat adanya konstruksi realitas inilah yang disebut sebagai doxa. Pandangan ini melekat pada semua masyarakat sebagai kebiasaan dalam kehidupan sosial. Ini tentu berbeda dengan keyakinan ortodoks maupun heterodoks yang menyiratkan kesadaran adanya perbedaan pandangan dan keyakinan dalam diri seseorang.

Beberapa penjelasan mengenai tindakan yang disebut oleh Habermas sebagai tindakan normatif, atau yang disebut oleh Borudieu sebagai doxa, 
telah disertai dengan penjelasan mengenai subjektivitas dari anggota masyarakat. Jika Habermas menyebutnya sebagai tindakan rasional instrumental, maka Bourdieu menyebutnya dengan keyakinan ortodoks dan heterodoks. Namun demikian, kedua tokoh ini sama-sama menyadari bahwa terdapat peran dari setiap subjek komunikasi, meski dalam lingkup antagonis sekalipun.

Pada dasarnya, setiap individu dapat saling menilai diri satu sama lain. Ini berkenaan dengan tindakan komunikasi sebagai akibat dari adanya stimulus yang kemudian dipersepsikan sebagai identitas diri pada masing-masing individu. Giddens menyebutkan bahwa identitas diri melibatkan kesadaran kognitif untuk "menjadi manusia" dan bukan hanya menjadi aktor refleksif, tetapi lebih jelas adalah untuk memiliki konsep sebagai manusia (Hill 2007, 48). Selanjutnya, Gross menyebutkan hal ini sebagai konsep diri, di mana konsep diri individu umumnya memiliki tiga komponen utama, yaitu: citra diri, harga diri, dan diri yang ideal. Adapun citra diri berada pada tingkat persepsi, sedangkan harga diri terletak pada sikap evaluatif pada diri sendiri, dan diri yang ideal merupakan keinginan untuk menjadi pribadi yang diidamkan (Hill 2007, 48).

Menilik pada kasus Taat Pribadi, sosok diri yang identik dengan kemewahan, gelar kerajaan, kesaktian dan unsur mistis, sampai pada predikat palsu yang kemudian mengubah kehidupannya secara sekejap, merupakan bentuk konstruksi sosial sebagai bagian dari persepsi masyarakat terhadap apa yang telah dicitrakan pada dirinya. Citra Taat Pribadi pada awalnya merujuk pada sosok yang terhormat yang kemudian disegani banyak orang, terutama bagi orang-orang yang kemudian menjadi pengikutnya. Terlebih, atribut sosial mengenai gelar kerajaan yang telah disematkan pada dirinya semakin mendukung image seorang Taat Pribadi pada saat itu.

Terkait penjelasan di atas, adapun citra ataupun konsep diri juga berkaitan dengan konsep kebenaran yang telah dijelaskan oleh Aristotle. Contohnya adalah ketika terdapat sebagian orang cantik karena memang cantik, dan ada orang cantik karena mencoba untuk terlihat cantik sehingga 
dipersepsikan cantik oleh orang lain. Lebih lanjut, ketika seseorang berdialektika dengan dirinya sendiri, maka orang tersebut akan mengetahui kebenaran dari citra dirinya. Lebih dari itu, dialektika dipandang mampu mengakomodasi sikap evaluatif seseorang untuk menghargai diri sendiri dan orang lain, dan juga menjadi pribadi yang lebih baik sesuai apa yang diinginkan.

Dialog dan dialektika bersifat pararel, di mana keduanya mampu lebih memperdalam pemahaman seseorang mengenai subjek dengan mempertimbangkannya dari berbagai sisi. Seseorang misalnya, bisa saja mampu melanjutkan apa yang dipertanyakan dan dijawab. Namun, setelah masalah atau topik dapat diidentifikasi dalam sebuah dialog sekalipun, Plato mengemukakan itu sama sekali tidak menjamin bahwa diskusi akan berakhir dengan kesepakatan, apalagi dengan kesimpulan (Nikulin 2000, $5)$.

Baik keduanya (dialog dan dialektika) akan terjadi ketika seseorang melakukan monolog. Dalam monolog, seseorang akan berdialog dan berdialektika dengan dirinya sendiri untuk mencari kebenaran. Proses ini akan terus terjadi selama manusia itu masih bisa berpikir. Jika dialog dan komunikasi masih dititikberatkan pada terciptanya konsensus, maka dialog dan dialektika dalam monolog berusaha untuk mewujudkan tujuan tersebut. Dengan demikian, penting bagi akademisi ilmu komunikasi untuk mempublikasikan tata cara bermonolog yang baik dan benar, agar setiap pembaca dapat mempelajarinya.

Guna menentukan sikap, seseorang perlu mengevaluasi tindakan yang dianggap benar, sedangkan norma-norma subjektif datang dari adanya kepercayaan normatif dan motivasi untuk patuh, yang mana dapat dipengaruhi oleh orang lain. Sikap dan norma-norma subjektif tersebut pada akhirnya membentuk maksud dari tindakan yang akan dilakukan. Terkait hal ini, adanya tindakan seseorang tentu sangat berpengaruh pada hubungan yang terjalin. Perlu ditegaskan bahwa semua bentuk hubungan melibatkan komunikasi di dalamnya, termasuk hubungan manusia dengan 
Tuhannya. Artinya, perlu ada tindak komunikasi yang baik agar hubungan yang sudah terjalin tetap harmonis.

Analisis lebih lanjut, klaim benar atau salah adalah tergantung pada hal itu sendiri, yang mana harus dapat dibuktikan kebenarannya oleh sarana dan metode dialektika. Menurut pengembang retorika, klaim atas kebenaran adalah jika pembicara dapat membuat sesuatu hal tampak kuat dan meyakinkan. Berbeda dengan anggapan shopistic bahwa kebenaran dapat diperoleh dengan berbagai cara, sebut saja seperti mengasingkan, membingungkan, dan akhirnya menaklukkan yang lain. Sebenarnya diskusi dialektika sendiri tidak bertujuan untuk menang secara pribadi, tetapi justru pada kebenaran antarpribadi (Nikulin 2000, 18).

Proses pencarian kebenaran dalam dialektika paling sesuai dengan hakikat komunikasi. Keduanya meniscayakan kesepahaman bersama, pemahaman bersama, dan kebenaran yang diyakini secara bersama-sama. Titik perbedaan dengan retorika jelas terletak pada tujuan komunikasi yang dilakukan. Jika dimasukkan dalam komunikasi intrapersonal, maka dialektika secara meyakinkan mencari relasi kebenaran di antara kemampuan dan harapan, sementara retorika lebih berpotensi untuk menjadikan diri atas perlindungan kamuflase yang bukan sebenarnya.

Dialektika dalam monolog pada akhirnya dapat meniscayakan pribadi yang selalu berusaha menjadi lebih baik. Proses evaluatif ini terjadi setiap saat ketika berdialektika dengan diri sendiri. Evaluasi tindakan dapat didasarkan pada kepercayaan normatif dan kepercayaan subjektif. Dengan demikian, tidak menutup kemungkinan untuk memperjuangkan nilai-nilai subjektif yang dianggap benar, dengan cara yang benar. Secara praktis, adanya kepercayaan atau apapun kebenaran yang diyakini nantinya akan membentuk sikap dan perilaku. Setiap komunikator atau komunikan akan tahu pada saat apa mereka bertindak sesuai dengan kehendak masyarakat, dan pada saat apa mereka bertindak sesuai dengan subjektivitasnya. 


\section{KESIMPULAN}

Komunikasi intrapersonal sebagai level awal dalam proses komunikasi memperlihatkan peran yang kuat pada diri individu melalui subjektivitasnya dalam membentuk dan mencapai objektivitas level komunikasi. Dalam hal ini, individu dalam kelompok atau organisasi memiliki ekspresi yang rasional dan subjektif. Ada peran yang dimainkan oleh komunikator dan komunikan ketika berkomunikasi satu sama lain. Hal inilah yang kemudian dapat berbentuk pesona yang sengaja diciptakan oleh individu guna memikat dan menanamkan kesamaan makna pada audiensnya.

Layaknya fenomena Dimas Kanjeng yang terjadi di Indonesia, objektivitas yang dihadirkan sebenarnya merupakan subjektivitas Taat Pribadi yang diolah secara mapan dan persuasif. Kemampuan atas tindakan komunikasi Taat Pribadi merujuk pada proses retorika dan persuasi yang dilakukan untuk bermain pada tingkat psikologis para pengikutnya hingga menguntungkan Taat Pribadi secara sepihak atau disensus. Terlebih, muncul konstruksi sosial atas citra Taat Pribadi, terutama melalui sejumlah atribut sosial yang melekat pada dirinya sehingga semakin memperkuat cara Taat Pribadi dalam mencitrakan dirinya di mata masyarakat.

Mengenai konteks disensus, lebih lanjut tidak selamanya merujuk pada tindakan subjektif yang berkonotasi negatif. Dalam simpulan terkait dialektika intrapribadi, seseorang dapat mengenali dan mengaplikasikan sistem kebaikan yang ada pada dirinya sehingga tindakan komunikatif yang diambil tidak merugikan orang lain. Lebih lanjut, terkait saran penelitian, diharapkan penelitian ini dapat menjadi salah satu rujukan terhadap penelitian selanjutnya, terutama dalam menganalisis tentang konsep dialog, dialektika, dan monolog, sebagai bagian dalam level komunikasi intrapersonal agar lebih menarik untuk ditelaah kembali. 


\section{DAFTAR PUSTAKA}

Aristotle. 1978. On Sophistical Refutations. Trans. E. S. Forster. Cambridge: Harvard University Press (Loeb Classical Library).

Berger, L. Peter, \& Luckmann, Thomas. 1966. The Social Construction of Reality. England: Penguin Group.

Bourdieu, Pierre. 1977. Outline Of A Theory Of Practice. Trans. Richard Nice. Great Britain: Cambridge University Press.

Faisol, Ahmad. 2016. Gelar Raja Nusantara untuk Dimas Kanjeng Taat Pribadi. Jakarta: Kompas.com. Diakses dari http://regional. kompas.com/ $\mathrm{read} / 2016 / 10 / 06 / 11410041 /$ gelar.raja.nusantara.untuk.dimas. kanjeng.taat.pribadi, tanggal 20 November 2016 Pukul 16.00 WIB.

Gramsci, Antonio. 1971. Selection From the Prison Notebooks, first edition. Trans. Quintin Hoare and Geoffrey Smith. New York: International Publishers.

Habermas, Jürgen. 1984. The Theory Of Communicative Action Volume One: Reason And The Rationalization Of Society. Trans. Thomas McCarthy. Boston: Beacon Press.

Hill, Anne, Watson, James, et.al. 2007. Key Themes in Interpersonal Communication: Cukture, Identity and Performance. Poland: The McGraw Hill Companies.

Littlejohn, Stephen W., dan Foss K. A. 2011. Theories Of Human Communication. Tenth Edition. Albuquerque. New Mexico: Wadsworth Publishing Company.

Mulyana, Deddy. 2010. Ilmu Komunikasi: Suatu Pengantar. Bandung: Remaja. Nikulin, Dmitri. 2000. Dialectic and Dialogue. California: Stanford University Press.

Nuris, Anwar. 2016. “Tindakan Komunikatif: Sekilas tentang Pemikiran Jürgen Habermas”. Al-Balagh. 1, 1:39-66.

Puchalska-Wasyl, M. 2010. "Dialogue, Monologue, and Change of Perspective -Three Forms of Dialogically". International Journal of Dialogical Science. 4, 1: 67-79.

Sartre, Jean-Paul. 1956. Being and Nothingness. New York: Washington Square Press.

. 1991. Critique of Dialectical Reason Volume II (Unfinished): The Intelligibility of History, Arlette ElkaÏm-Sartre, eds. Trans. Quintin Hoare. London: Verso. 
44 Ferry Adhi Dharma - Dialektika Komunikasi Intrapersonal

Smith, W. John. 1977. The Behavior of Communicating An Ethological Approach. USA: Harvard University Press. 